\title{
Benefits and risks of noninvasive oxygenation strategy in COVID-19: a multicenter, prospective cohort study (COVID-ICU) in 137 hospitals
}

\author{
COVID-ICU group, for the REVA network, COVID-ICU investigators ${ }^{*}$
}

\begin{abstract}
Rational: To evaluate the respective impact of standard oxygen, high-flow nasal cannula (HFNC) and noninvasive ventilation (NIV) on oxygenation failure rate and mortality in COVID-19 patients admitted to intensive care units (ICUs)

Methods: Multicenter, prospective cohort study (COVID-ICU) in 137 hospitals in France, Belgium, and Switzerland. Demographic, clinical, respiratory support, oxygenation failure, and survival data were collected. Oxygenation failure was defined as either intubation or death in the ICU without intubation. Variables independently associated with oxygenation failure and Day-90 mortality were assessed using multivariate logistic regression.
\end{abstract}

Results: From February 25 to May 4, 2020, 4754 patients were admitted in ICU. Of these, 1491 patients were not intubated on the day of ICU admission and received standard oxygen therapy (51\%), HFNC (38\%), or NIV (11\%) $(P<0.001)$. Oxygenation failure occurred in 739 (50\%) patients (678 intubation and 61 death). For standard oxygen, HFNC, and NIV, oxygenation failure rate was 49\%, 48\%, and 60\% ( $P<0.001)$. By multivariate analysis, HFNC (odds ratio [OR] 0.60, 95\% confidence interval [CI] 0.36-0.99, $P=0.013$ ) but not NIV (OR 1.57, 95\% Cl 0.78-3.21) was associated with a reduction in oxygenation failure). Overall 90-day mortality was $21 \%$. By multivariable analysis, HFNC was not associated with a change in mortality $(\mathrm{OR} 0.90,95 \% \mathrm{Cl} 0.61-1.33)$, while NIV was associated with increased mortality $(\mathrm{OR} 2.75,95 \% \mathrm{Cl}$ $1.79-4.21, P<0.001)$.

Conclusion: In patients with COVID-19, HFNC was associated with a reduction in oxygenation failure without improvement in 90-day mortality, whereas NIV was associated with a higher mortality in these patients. Randomized controlled trials are needed.

Keywords: Acute respiratory distress syndrome, Mechanical ventilation, COVID-19, Outcome, High-flow nasal cannula, Intubation, Mortality, Acute respiratory failure

*Correspondence: alexandre.demoule@aphp.fr

Service de Médecine Intensive - Réanimation, Hôpital Pitié-Salpêtrière, 83 Boulevard de l'Hôpital, 75013 Paris, France

Management and Writing Committee and COVID-ICU Investigators are listed in the acknowledgement section, at the end of the manuscript

\section{Introduction}

Severe acute respiratory syndrome coronavirus 2 (SARS$\mathrm{CoV}-2)$ is the causative agent of the ongoing coronavirus disease 2019 (COVID-19) pandemic. Understanding how clinicians can address the demand for emergency mass critical care and fine-tune the standard of care regarding oxygenation management is of the utmost importance. original author(s) and the source, provide a link to the Creative Commons licence, and indicate if changes were made. The images or other third party material in this article are included in the article's Creative Commons licence, unless indicated otherwise in a credit line to the material. If material is not included in the article's Creative Commons licence and your intended use is not permitted by statutory regulation or exceeds the permitted use, you will need to obtain permission directly from the copyright holder. To view a copy of this licence, visit http://creativecommons.org/licenses/by/4.0/. The Creative Commons Public Domain Dedication waiver (http://creativeco mmons.org/publicdomain/zero/1.0/) applies to the data made available in this article, unless otherwise stated in a credit line to the data. 
For instance, guidance about how to allocate scarce critical care resources such as ventilators should be made using data showing that safe alternatives to standard oxygen therapy can avoid intubation without lessening survival probabilities.

In patients with de novo acute respiratory failure admitted to the intensive care unit (ICU), high-flow nasal cannula oxygen (HFNC) and noninvasive mechanical ventilation (NIV) improve oxygenation and reduce inspiratory effort and the work of breathing [1-3]. Highflow nasal cannula oxygen has shown clinical benefit by reducing the intubation rate [4], and its use is now recommended in de novo acute respiratory failure [5]. Noninvasive ventilation decreases the intubation rate [6], but NIV failure and subsequent intubation is associated with higher mortality compared to first-line intubation [7], and NIV is not recommended in de novo acute respiratory failure [6].

In COVID-19 patients, recent data suggest that HFNC and NIV are associated with a reduction in intubation rate, but without a clear benefit on mortality $[8,9]$.

We hypothesized that HFNC and NIV could be beneficial to the outcome of COVID-19 patients admitted to the ICU for acute respiratory failure. This study comprised a secondary analysis of the large international COVID-ICU study [10] with the following specific objectives: 1) to quantify the respective use of standard oxygen, HFNC, and NIV; 2) to determine oxygenation failure rate (i.e., intubation rate or death in the ICU without intubation) of standard oxygen, HFNC, and NIV and to evaluate the impact of HFNC and NIV on oxygen failure; and 3) to evaluate whether HFNC and NIV use is associated with a reduction in mortality.

\section{Methods}

\section{Study design, patients}

COVID-ICU is a multicenter, prospective cohort study conducted in 149 ICUs from 137 centers, across three countries (France, Switzerland, and Belgium). The main characteristics of these ICUs have been described elsewhere [10]. Centers were invited to participate by public announcements and through the REVA network (70 centers were active members of this network). COVIDICU received approval from the ethical committee of the French Intensive Care Society (CE-SRLF 20-23) in accordance with local regulations. All patients or close relatives were informed that their data were included in the COVID-ICU cohort.

All consecutive patients over 16 years of age admitted to participating ICUs between February 25, 2020, and May 4, 2020, with laboratory-confirmed SARS-CoV-2 infection, were included. Laboratory confirmation for SARS-Cov-2 was defined as a positive result of real-time reverse transcriptase-polymerase chain reaction (RTPCR) assay from either nasal or pharyngeal swabs, or lower respiratory tract aspirate. For the purposes of the present post hoc analysis, only patients who were not intubated on the day of ICU admission were included.

\section{Data collection}

Day 1 was defined as the first day that the patient was in the ICU at $10 \mathrm{am}$. Each day, the study investigators completed a standardized electronic case report form. Baseline information collected at ICU admission was age, sex, body mass index, active smoking, Simplified Acute Physiology Score II score [11], Sequential Organ Failure Assessment [12], comorbidities, immunodeficiency (if present), clinical frailty scale [13], date of the first symptom, date of hospital, and ICU admissions. The case report form prompted investigators to provide a daily expanded data set including the use of respiratory support devices (standard oxygen, HFNC, or NIV), the need for invasive mechanical ventilation, the fraction of inspired oxygen $\left(\mathrm{FiO}_{2}\right)$, blood gases at Day $1\left(\mathrm{PaO}_{2} /\right.$ $\mathrm{FiO}_{2}$ was calculated in all patients by converting $\mathrm{O}_{2}$ flow to estimated $\mathrm{FiO}_{2}$, see Additional file 1: Table S1), and standard laboratory parameters. Some patients received more than one of the three oxygenation techniques, in which case the most invasive was retained for further analyses, assuming NIV to be more invasive than HFNC and HFNC to be more invasive than standard oxygen.

Patient outcomes included the date of invasive mechanical ventilation, the date of ICU and hospital discharge, and vital status at ICU discharge, hospital discharge, and 28, 60, and 90 days after ICU admission. Patients who received invasive mechanical ventilation or who died before ICU discharge without being intubated were classified as oxygenation strategy failure. Patients treated with an oxygenation technique until assistance was no longer required were classified as success.

\section{Statistical analyses}

Characteristics of patients were described as frequencies and percentages for categorical variables, and as means and standard deviations or medians and interquartile ranges for continuous variables. Categorical variables were compared by chi-square or Fisher's exact test, and continuous variables were compared by Student's $t$ test or Wilcoxon's rank-sum test. Kaplan-Meier overall survival curves until Day 90 were computed and were compared using log-rank tests.

Variables associated with oxygenation failure, defined as intubation or death in the ICU without intubation, were assessed using multivariate logistic regression analyses, and the results are given as odds ratio (OR) with their $95 \%$ confidence interval (CI). 
Baseline risk factors of death at Day 90 were assessed within the whole cohort using univariate and multivariate cox regression. Baseline variables (i.e., obtained during the first $24 \mathrm{~h}$ in the ICU) included in the multivariate model were defined a priori, and no variable selection was performed. A sensitivity analysis with multiple imputations was also performed.

A $P$ value $<0.05$ was considered statistically significant. Statistical analyses were conducted with R v3.5.1.

\section{Results}

\section{Study population and oxygenation and ventilation modalities}

Over the 10-week study period, 4754 patients were enrolled, of them 510 were lost to follow-up at Day 90 . Vital status at Day 90 was available for the remaining 4244 patients. Data on initial oxygenation strategy were missing in 118 patients.

Figure 1 depicts the oxygenation and ventilation modalities following ICU admission. A total of 2635 patients were intubated on the day of ICU admission (time from ICU admission to intubation 2.0 [0.5-7.2] hours) and were excluded from the present analysis. The remaining 1491 patients were not intubated on the day of ICU admission.

Table 1 shows the demographic, clinical, and biological characteristics of the 1491 patients who were not intubated on ICU admission, overall and for each oxygenation strategy. Standard oxygen therapy, HFNC, and NIV were applied to 766 (51\%), 567 (38\%), and 158 (11\%) patients, respectively. Among patients who received NIV, 11 (1\%) received continuous positive airway pressure and the remaining 147 (10\%) patients received pressure support ventilation. Noninvasive ventilation was exclusively delivered with a bucconasal or face facemask; helmet was not used. Patients who received either HFNC or NIV were older, had a higher SOFA score, were more severely hypoxemic, and were admitted to the ICU a longer period of time after first symptoms. The proportion of patients who received HFNC and NIV was higher between March 29 and May 4, 2020, than between February 25 and March 28, 2020. In patients receiving standard oxygen, oxygen flow was $6(4-10) \mathrm{L} / \mathrm{min}$. In those receiving HFNC,

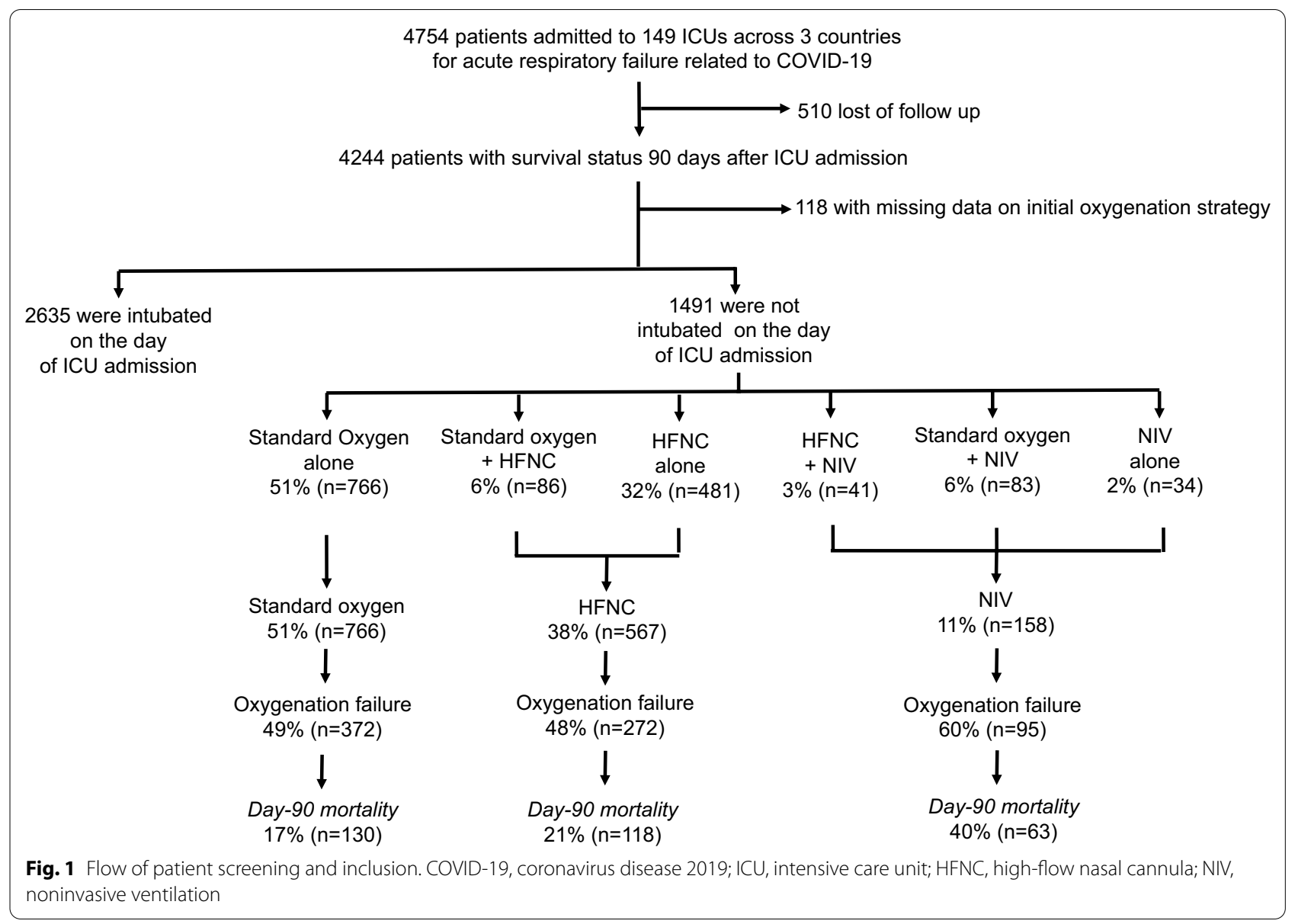


Table 1 Demographic, clinical, and biological characteristics of 1491 patients not intubated on the day of intensive care unit (ICU) admission, according to oxygenation strategy

\begin{tabular}{|c|c|c|c|c|c|c|}
\hline & No & $\begin{array}{l}\text { All patients } \\
(n=1491)\end{array}$ & $\begin{array}{l}\text { Standard oxygen } \\
(n=766)\end{array}$ & $\begin{array}{l}\text { HFNC } \\
(n=567)\end{array}$ & $\begin{array}{l}\text { NIV } \\
(n=158)\end{array}$ & $P$ value \\
\hline Age, years & 1491 & $63(54-71)$ & $61(53-70)$ & $64(55-72)$ & $65(56-72)$ & 0.005 \\
\hline Women, $n(\%)$ & 1488 & $397(27)$ & $212(28)$ & $140(25)$ & $45(29)$ & 0.389 \\
\hline Body mass index, $\mathrm{kg} / \mathrm{m}^{2}$ & 1370 & $28(25-31)$ & $28(25-32)$ & $28(25-31)$ & $29(26-33)$ & 0.334 \\
\hline$\geq 30 \mathrm{~kg} / \mathrm{m}^{2}, n(\%)$ & 1370 & $504(37)$ & $260(37)$ & $179(35)$ & $65(45)$ & 0.085 \\
\hline Active smokers, $n(\%)$ & 1465 & $67(5)$ & $35(5)$ & $19(4)$ & $13(8)$ & 0.037 \\
\hline SAPS II score & 1398 & $30(23-37)$ & $27(21-35)$ & $32(27-39)$ & $33(26-41)$ & $<0.001$ \\
\hline SOFA score at ICU admission & 1290 & $3(2-4)$ & $2(2-4)$ & $3(2-4)$ & $3(2-5)$ & $<0.001$ \\
\hline Treated hypertension, $n(\%)$ & 1485 & $687(46)$ & $331(43)$ & $263(47)$ & $93(59)$ & 0.001 \\
\hline Known diabetes, $n(\%)$ & 1486 & $409(28)$ & $206(27)$ & $145(26)$ & $58(37)$ & 0.018 \\
\hline Immunodeficiency ${ }^{\mathrm{a}}, n(\%)$ & 1479 & $102(7)$ & $42(6)$ & $48(9)$ & $12(8)$ & 0.090 \\
\hline Clinical frailty scale & 1379 & $2(2-3)$ & $2(1-3)$ & $2(2-3)$ & $2(2-4)$ & $<0.001$ \\
\hline $\begin{array}{l}\text { Time between first symptoms and ICU } \\
\text { admission, days }\end{array}$ & 1435 & $9(6-12)$ & $8(6-11)$ & $9(7-12)$ & $9(7-12)$ & $<0.001$ \\
\hline \multicolumn{7}{|l|}{ During the first $24 \mathrm{~h}$ in ICU } \\
\hline Hemodynamic component of the SOFA & 1435 & $0(0-0)$ & $0(0-0)$ & $0(0-0)$ & $0(0-0)$ & 0.351 \\
\hline Renal component of the SOFA & 1416 & $0(0-0)$ & $0(0-0)$ & $0(0-0)$ & $0(0-0)$ & 0.047 \\
\hline Corticosteroids $^{\mathrm{b}}, n(\%)$ & 1476 & $165(11)$ & $50(7)$ & $85(15)$ & $30(19)$ & $<0.001$ \\
\hline \multicolumn{7}{|l|}{ Blood gases } \\
\hline $\mathrm{pH}$ & 1365 & $7.46(7.42-7.48)$ & $7.45(7.42-7.48)$ & $7.46(7.44-7.49)$ & $7.44(7.41-7.48)$ & $<0.001$ \\
\hline $\mathrm{PaCO}_{2}, \mathrm{mmHg}$ & 1367 & $36(32-40)$ & $36(33-40)$ & $36(32-39)$ & $36(32-43)$ & 0.039 \\
\hline $\mathrm{PaO}_{2} / \mathrm{FiO}_{2}{ }^{\mathrm{C}}$ & 1216 & $122(82-177)$ & $154(89-219)$ & $104(77-134)$ & $128(86-169)$ & $<0.001$ \\
\hline $\mathrm{HCO}_{3}, \mathrm{mmol} / \mathrm{L}$ & 1357 & $25(23-27)$ & $25(23-27)$ & $25(23-27)$ & $25(23-28)$ & 0.769 \\
\hline Lactate, $\mathrm{mmol} / \mathrm{L}$ & 1281 & $1.1(0.9-1.5)$ & $1.1(0.8-1.5)$ & $1.2(0.9-1.5)$ & $1.1(0.9-1.5)$ & 0.039 \\
\hline \multicolumn{7}{|l|}{ Biology } \\
\hline Lymphocyte count, $\times 10^{9} / \mathrm{L}$ & 1199 & $0.8(0.6-1.2)$ & $0.9(0.6-1.2)$ & $0.8(0.6-1.1)$ & $0.8(0.6-1.1)$ & 0.016 \\
\hline Platelet count, $\times 10^{9} / \mathrm{L}$ & 1342 & $222(167-289)$ & $205(159-275)$ & $236(177-302)$ & $241(177-294)$ & $<0.001$ \\
\hline Total bilirubin, $\mu \mathrm{mol} / \mathrm{L}$ & 1023 & $9(7-12)$ & $9(7-12)$ & $9(7-12)$ & $9(7-13)$ & 0.085 \\
\hline Serum creatinine, $\mu \mathrm{mol} / \mathrm{L}$ & 1369 & $71(59-94)$ & $72(60-91)$ & $71(57-92)$ & $74(59-110)$ & 0.098 \\
\hline D-dimers, $\mu \mathrm{g} / \mathrm{L}$ & 548 & $1159(647-2204)$ & $1080(675-2000)$ & $1282(708-2930)$ & $1040(538-1939)$ & 0.097 \\
\hline Period of admission & 1491 & & & & & $<0.001$ \\
\hline February 25 to March 28, 2020, n (\%) & & $713(48)$ & $479(63)$ & $187(33)$ & $47(30)$ & \\
\hline March 29 to May 4, 2020, n (\%) & & $778(52)$ & $287(37)$ & $380(67)$ & $111(70)$ & \\
\hline Do-not-intubate, $n$ (\%) & 1491 & $155(10 \%)$ & $65(8 \%)$ & $54(10 \%)$ & $36(23 \%)$ & $<0.001$ \\
\hline
\end{tabular}

Results are expressed as $n$ (\%) or median (25th-75thpercentiles)

HFNC high-flow nasal cannula, NIV noninvasive ventilation, SAPS simplified acute physiology score, SOFA sequential organ failure assessment, $P_{a C O_{2}}$ partial pressure of carbon dioxide, $\mathrm{PaO}_{2} / \mathrm{FiO}_{2}$ partial pressure of oxygen to fraction of inspired oxygen ratio, $\mathrm{HCO} 3$ bicarbonate

${ }^{a}$ Defined as hematological malignancies, active solid tumor, or having received specific anti-tumor treatment within a year, solid organ transplant, human immunodeficiency virus, or immunosuppressants

${ }^{b}$ Irrespective of the dose and the indication

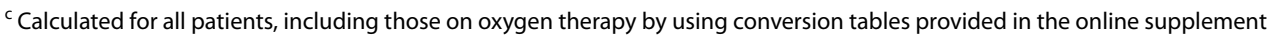

flow was $50(40-60) \mathrm{L} / \mathrm{min}$ and $\mathrm{FiO}_{2}$ was $70(60-90) \%$. In those receiving NIV, pressure support level was 8 (6-10) $\mathrm{cmH}_{2} \mathrm{O}$, positive end-expiratory pressure was 7 (6-8) $\mathrm{cmH}_{2} \mathrm{O}$ and $\mathrm{FiO}_{2}$ was $60(50-80) \%$. Overall, a do-not-intubate decision had been taken in 155 (10\%) patients. This proportion was higher in patients who received NIV $(23 \%, n=36)$ than in those who received
HFNC $(10 \%, n=54)$ or standard oxygen $(8 \%, n=65$, $P<0.001)$.

\section{Factors associated with intubation and impact of HFNC and NIV on intubation}

Invasive mechanical ventilation was started in 678 patients, and 61 patients died in the ICU without being 
intubated. These 739 (50\%) patients were classified as oxygenation failure. The remaining 752 (50\%) patients were classified as oxygenation success.

Table 2 shows the intubation rate, mortality, and length of stay in patients who were not intubated on the day of admission. Intubation rate was not different between patients treated with standard oxygen, HFNC, and NIV. Intubation occurred after a longer period of time in patients treated with HFNC and NIV than in those treated with standard oxygen (Table 2). The proportion of patients who died without being intubated as well as the oxygenation failure rate were higher in the NIV group compared to those who received HFNC or standard oxygen. Additional file 1: Table S1 shows the univariate analysis of factors associated with oxygenation failure in patients who were not intubated on ICU admission. Variables associated with oxygenation failure by multivariable analysis were: severity as assessed by the SAPS II, time between the first symptoms and ICU admission, oxygenation technique, higher renal component of the SOFA score, lower $\mathrm{PaO}_{2} / \mathrm{FiO}_{2}$, higher blood lactate, and admission period after March 29, 2021 (Table 3). HFNC (OR 0.60, 95\% CI 0.36-0.99, $P=0.013$ ) but not NIV (OR 1.57, 95\% CI 0.78-3.21) was associated with a reduction in oxygenation failure. The cumulative incidence of oxygenation failure for standard oxygen, HFNC, and NIV is shown in Fig. 2, Panel A.

\section{Factors associated with mortality and impact of HFNC and NIV on mortality}

Overall 90 -day mortality was $21 \%$. Additional file 3 : Table S3 shows the univariate analysis of the factors associated with 90-day mortality in patients who were not intubated on ICU admission. By multivariable analysis, factors associated with mortality were older age, known diabetes, severity as assessed by the SAPS II, higher frailty, shorter time between the first symptoms and ICU admission, lower $\mathrm{PaO}_{2} / \mathrm{FiO}_{2}$, and lower platelet count (Table 4). HFNC was not associated with a change in mortality (OR $0.90,95 \%$ CI $0.61-1.33$ ), but NIV was associated with an increased mortality (OR $2.75,95 \% \mathrm{CI}$ 1.79-4.21, $P<0.001)$.

The same analysis rerun after multiple imputations of missing data found similar results (see Additional file 4: Table S4).

Kaplan-Meier survival estimates according to oxygenation technique are provided in Fig. 2, Panel B, and showed increased mortality in the group initially treated with NIV.

\section{Discussion}

In patients with acute respiratory failure due to COVID19 and who were not intubated on the day of ICU admission, the results of our study showed, for each specific objective, the following: (1) HFNC and NIV, respectively, were used in $38 \%$ and $11 \%$ of patients, (2) HFNC but not NIV was independently associated with a reduction in oxygenation failure, and (3) HFNC was not associated with a reduction in 90-day mortality, and NIV was associated with increased 90-day mortality.

Despite international guidelines recommending early intubation of COVID-19 patients to protect healthcare workers [14] and despite experts recommending early intubation to prevent self-inflected lung injury in this patient population [15], HFNC and NIV were used

Table 2 Outcome of 1491 patients not intubated on the day of intensive care unit (ICU) admission, according to oxygenation strategy

\begin{tabular}{|c|c|c|c|c|c|c|}
\hline & No & $\begin{array}{l}\text { All patients } \\
(n=1491)\end{array}$ & $\begin{array}{l}\text { Standard oxygen } \\
(n=766)\end{array}$ & $\begin{array}{l}\text { HFNC } \\
(n=567)\end{array}$ & $\begin{array}{l}\text { NIV } \\
(n=158)\end{array}$ & $P$ value \\
\hline Invasive mechanical ventilation, $n(\%)$ & 1491 & $678(45)$ & $359(47)$ & $242(43)$ & $77(49)$ & 0.217 \\
\hline $\begin{array}{l}\text { Time between ICU admission and invasive } \\
\text { mechanical ventilation, days }\end{array}$ & 635 & $2(1-3)$ & $2(1-2)$ & $2(1-3)$ & $2(1-3)$ & 0.012 \\
\hline ICU mortality without being intubated, $n(\%)$ & 1491 & $61(4)$ & $13(2)$ & $30(5)$ & $18(11)$ & $<0.001$ \\
\hline Oxygenation failure rate, $n(\%)$ & 1491 & $739(50)$ & $372(49)$ & $272(48)$ & $95(60)$ & $<0.001$ \\
\hline ICU mortality, $n(\%)$ & 1487 & $269(18)$ & $108(14)$ & $109(19)$ & $52(33)$ & $<0.001$ \\
\hline ICU length of stay, days & 1477 & $8(3-18)$ & $7(3-16)$ & $9(5-18)$ & $9(4-20)$ & $<0.001$ \\
\hline Hospital mortality, $n(\%)$ & 1439 & $307(21)$ & $127(17)$ & $118(22)$ & $62(40)$ & $<0.001$ \\
\hline Hospital length of stay, days & 1400 & $17(11-28)$ & $16(10-27)$ & $18(12-29)$ & $16(11-27)$ & 0.0039 \\
\hline Day 28 mortality, n (\%) & 1491 & $276(19)$ & $115(15)$ & $106(19)$ & $55(35)$ & $<0.001$ \\
\hline Day 60 mortality, n (\%) & 1491 & $308(21)$ & $130(17)$ & $117(21)$ & $61(39)$ & $<0.001$ \\
\hline Day 90 mortality, $n$ (\%) & 1491 & $311(21)$ & $130(17)$ & $118(21)$ & $63(40)$ & $<0.001$ \\
\hline
\end{tabular}

Results are expressed as $n$ (\%) or median (25th-75th percentiles)

HFNC high-flow nasal cannula, NIV noninvasive ventilation, ICU intensive care unit 
Table 3 Factors associated with oxygenation failure by multivariate analysis among patients who were notintubated on the day of ICU admission

\begin{tabular}{|c|c|c|c|c|}
\hline & Univariate OR $(95 \% \mathrm{Cl})$ & $P$ value & Multivariate OR $(95 \% \mathrm{Cl})$ & $P$ value \\
\hline Age, years & & $<0.001$ & & 0.078 \\
\hline$\leq 75$ & - & & - & \\
\hline $60-74$ & $0.98(0.72-1.32)$ & & $1.74(0.93-3.28)$ & \\
\hline $40-59$ & $0.58(0.43-0.80)$ & & $1.33(0.68-2.64)$ & \\
\hline$<40$ & $0.45(0.27-0.74)$ & & $0.54(0.14-1.82)$ & \\
\hline Genre, woman & $0.73(0.58-0.92)$ & 0.009 & $0.72(0.44-1.19)$ & 0.203 \\
\hline Body mass index, $\mathrm{kg} / \mathrm{m}^{2}$ & - & 0.870 & - & 0.178 \\
\hline \multicolumn{5}{|l|}{$<25$} \\
\hline $25-29$ & $1.05(0.79-1.40)$ & & $0.89(0.51-1.55)$ & \\
\hline $30-34$ & $1.18(0.86-1.63)$ & & $1.58(0.83-3.01)$ & \\
\hline $35-39$ & $1.14(0.76-1.72)$ & & $1.01(0.45-2.26)$ & \\
\hline$\geq 40$ & $1.05(0.60-1.85)$ & & $2.42(0.73-8.26)$ & \\
\hline Active smokers & $1.00(0.61-1.63)$ & 0.996 & $0.83(0.31-2.20)$ & 0.701 \\
\hline SAPS II score & $1.05(1.04-1.06)$ & $<0.001$ & $1.07(1.04-1.09)$ & $<0.001$ \\
\hline Treated hypertension & $1.35(1.10-1.66)$ & 0.004 & $0.79(0.51-1.23)$ & 0.300 \\
\hline Known diabetes & $1.31(1.05-1.65)$ & 0.019 & $0.74(0.45-1.20)$ & 0.222 \\
\hline Immunodepression ${ }^{\mathrm{a}}$ & $1.43(0.95-2.15)$ & 0.085 & $0.85(0.32-2.23)$ & 0.747 \\
\hline Frailty score & & 0.009 & - & 0.875 \\
\hline $1-3$ & - & & & \\
\hline 4 & $1.70(1.16-2.51)$ & & $1.27(0.51-3.32)$ & \\
\hline $5-9$ & $1.46(0.93-2.31)$ & & $1.07(0.37-3.04)$ & \\
\hline Delay between first signs and ICU admission, days & & $<0.001$ & - & 0.012 \\
\hline$<4$ & - & & & \\
\hline $4-7$ & $0.84(0.58-1.20)$ & & $0.74(0.35-1.53)$ & \\
\hline$\geq 8$ & $0.44(0.31-0.62)$ & & $0.42(0.20-0.87)$ & \\
\hline \multicolumn{5}{|l|}{ During the first $24 \mathrm{~h}$ in ICU } \\
\hline Oxygenation technique & & 0.019 & & 0.013 \\
\hline Standard oxygen & - & & - & \\
\hline HFNC & $0.98(0.79-1.21)$ & & $0.60(0.36-0.99)$ & \\
\hline NIV & $1.60(1.13-2.27)$ & & $1.57(0.78-3.21)$ & \\
\hline Cardiovascular component of the SOFA score $\geq 3$ & $3.37(1.75-7.00)$ & $<0.001$ & $1.45(0.37-7.53)$ & 0.608 \\
\hline Renal component of the SOFA score $\geq 3$ & $1.06(0.68-1.66)$ & 0.785 & $0.35(0.12-0.99)$ & 0.048 \\
\hline Corticosteroids ${ }^{b}$ & $0.76(0.55-1.05)$ & 0.096 & $0.93(0.46-1.88)$ & 0.847 \\
\hline $\mathrm{pH}$ & $0.12(0.02-0.71)$ & 0.010 & $0.95(0.02-59.91)$ & 0.980 \\
\hline $\mathrm{PaCO}_{2}, \mathrm{mmHg}$ & $1.00(1.00-1.00)$ & 0.856 & $0.97(0.94-1.00)$ & 0.064 \\
\hline $\mathrm{PaO}_{2} / \mathrm{FiO}_{2}{ }^{\mathrm{C}}, \mathrm{mmHg}$ & & $<0.001$ & - & $<0.001$ \\
\hline$\leq 100$ & - & & & \\
\hline $101-200$ & $0.43(0.33-0.55)$ & & $0.32(0.20-0.50)$ & \\
\hline $201-300$ & $0.26(0.17-0.37)$ & & $0.21(0.10-0.41)$ & \\
\hline$>300$ & $0.25(0.15-0.43)$ & & $0.23(0.07-0.71)$ & \\
\hline $\mathrm{HCO} 3, \mathrm{mmol} / \mathrm{L}$ & $0.97(0.94-0.99)$ & 0.006 & $1.00(0.97-1.03)$ & 0.993 \\
\hline Lactate, $\mathrm{mmol} / \mathrm{L}$ & $1.31(1.12-1.57)$ & $<0.001$ & $1.28(1.06-1.67)$ & 0.001 \\
\hline Lymphocyte count $<1 \times 10^{9} / \mathrm{L}$ & $1.59(1.26-2.01)$ & $<0.001$ & $1.20(0.79-1.85)$ & 0.394 \\
\hline Platelet count $<150 \times 10^{9} / \mathrm{L}$ & $1.76(1.32-2.37)$ & $<0.001$ & $1.16(0.65-2.06)$ & 0.621 \\
\hline Total bilirubin concentration, $\mu \mathrm{mol} / \mathrm{L}$ & $1.00(0.99-1.01)$ & 0.990 & $1.00(0.97-1.02)$ & 0.769 \\
\hline ICU admission period, March 29 to May 4, 2020 & $0.63(0.51-0.77)$ & $<0.001$ & $0.46(0.29-0.72)$ & $<0.001$ \\
\hline
\end{tabular}

OR odds ratio, CI confidence interval, HFNC high-flow nasal cannula, NIV noninvasive ventilation, SAPS Simplified Acute Physiology Score, SOFA Sequential Organ Failure Assessment, $\mathrm{PaCO}_{2}$ partial pressure of carbon dioxide, $\mathrm{PaO}_{2} / \mathrm{FiO}_{2}$ partial pressure of oxygen to fraction of inspired oxygen ratio, $\mathrm{HCO} 3$ bicarbonate

a Defined as hematological malignancies, active solid tumor, or having received specific anti-tumor treatment within a year, solid organ transplant, human immunodeficiency virus, or immunosuppressants 
Table 3 (continued)

${ }^{\mathrm{b}}$ Irrespective of the dose and the indication

${ }^{C}$ Calculated for all patients, including those on oxygen therapy by using conversion tables provided in the online supplement
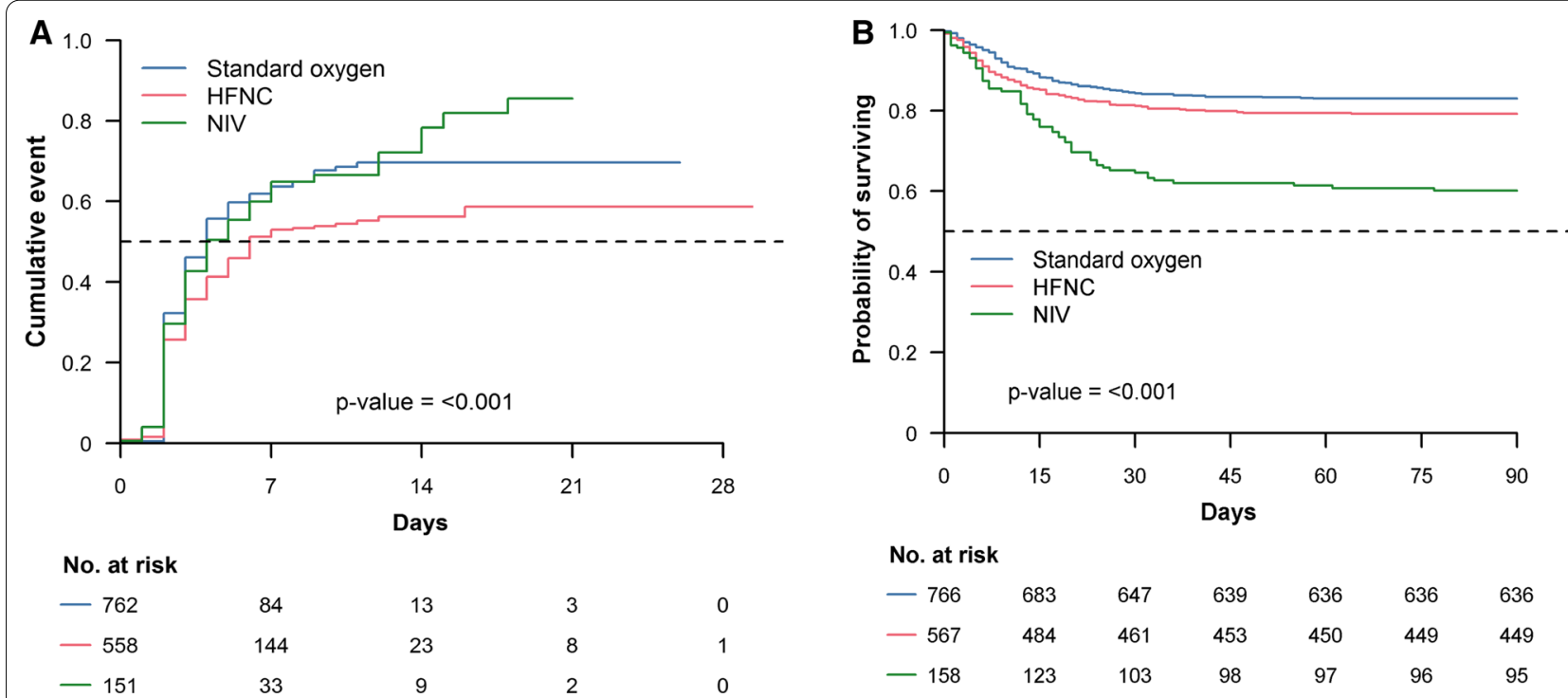

No. at risk

$\begin{array}{rc}-762 & 84 \\ -558 & 144 \\ -151 & 33\end{array}$

13

23

9

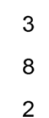

2

Fig. 2 Left panel: Cumulative incidence of oxygenation failure according to the oxygenation technique in patients not intubated on the day of intensive care unit admission. Right panel: Cumulative incidence of hospital mortality according to the oxygenation technique. HFNC, high-flow nasal cannula; NIV, noninvasive ventilation;

increasingly during the first wave of the COVID-19 pandemic in France, Belgium, and Switzerland [8, 10, 16, 17]. The proportion of patients who received NIV was comparable to that reported by various COVID-19 cohort studies conducted in Europe and the USA [18-20]. It was also similar to the proportion of non-COVID-19 patients who received NIV in the LUNGSAFE cohort study [21]. On the other hand, the proportion of patients who received HFNC was higher in the present study than in these COVID and non-COVID cohorts. It is important to point that, in de novo acute hypoxemic respiratory failure, NIV is not recommended [6], while HFNC is now recommended [5].

The proportion of patients who were intubated was similar to that reported in other cohorts of COVID-19 patients $[18,22]$. However, the impact of HFNC and NIV on oxygenation failure differed, with HFNC but not NIV being independently associated with a reduction in oxygenation failure. This benefit of HFNC has been reported in severe hypoxemic non-COVID-19 patients [4, 23], and more recently in COVID-19 patients $[9,18]$. In de novo acute hypoxemic respiratory failure, the benefit of NIV is debated [6], and its use does not seem to be associated with a clear reduction in intubation rate in nonCOVID-19 patients [6]. In COVID-19 patients, although retrospective studies have suggested a potential benefit of NIV on intubation $[9,18]$, a randomized control trial showed a reduction in intubation rate in patients receiving helmet NIV, but no improvement in the number of days free of respiratory support [22]. It is of note that we chose oxygenation failure (defined as intubation or death in the ICU without intubation) as the outcome rather than intubation alone as it is well established that HFNC and NIV may be given to do-not-intubate patients, as a ceiling therapy $[24,25]$. This was the case in our cohort, where $4 \%$ patients died without being intubated, which is clearly a failure of oxygenation. Omitting these patients and choosing intubation as the sole outcome would have underestimated the oxygenation failure rate.

We did not find any impact of HFNC on mortality, while NIV was associated with increased mortality. In non-COVID-19 patients, there is not a clear benefit of either HFNC or NIV on mortality $[4,6]$. In some patients, NIV could even be more deleterious than intubation [7]. One hypothesis is that a low expiratory tidal volume is almost impossible to achieve with NIV in patients with de novo acute hypoxemic respiratory failure [26], and a high tidal volume under NIV $((\geq 9 \mathrm{~mL} / \mathrm{kg}$ of ideal body weight $[26,27])$ could cause patient self-inflicted lung injury, which in turn may worsen the severity of lung 
Table 4 Factors associated with 90-day mortality by multivariate analysis among patients who were not intubated on the day of ICU admission

\begin{tabular}{|c|c|c|c|c|c|}
\hline & $n$ & Univariate HR $(95 \% \mathrm{Cl})$ & $P$ value & Multivariate HR $(95 \% \mathrm{Cl})$ & $P$ value \\
\hline Age, years & 1491 & & $<0.001$ & & $<0.001$ \\
\hline$\leq 75$ & & - & & - & \\
\hline $60-74$ & & $0.43(0.33-0.56)$ & & $0.60(0.41-0.89)$ & \\
\hline $40-59$ & & $0.20(0.14-0.27)$ & & $0.38(0.23-0.63)$ & \\
\hline$<40$ & & $0.17(0.09-0.34)$ & & $0.33(0.10-1.14)$ & \\
\hline Genre, woman & 1488 & $0.85(0.65-1.10)$ & 0.216 & $0.77(0.52-1.15)$ & 0.893 \\
\hline Body mass index, $\mathrm{kg} / \mathrm{m}^{2}$ & 1370 & & 0.254 & & 0.072 \\
\hline$<25$ & & - & & - & \\
\hline $25-29$ & & $0.95(0.70-1.27)$ & & $0.92(0.61-1.41)$ & \\
\hline $30-34$ & & $0.74(0.52-1.06)$ & & $0.79(0.48-1.28)$ & \\
\hline $35-39$ & & $0.67(0.41-1.08)$ & & $0.40(0.18-0.86)$ & \\
\hline$\geq 40$ & & $0.97(0.53-1.75)$ & & $1.01(0.45-2.28)$ & \\
\hline SAPS II score & 1398 & $1.04(1.03-1.05)$ & $<0.001$ & $1.03(1.01-1.04)$ & $<0.001$ \\
\hline Treated hypertension & 1485 & $1.45(1.16-1.82)$ & $<0.001$ & $0.78(0.54-1.11)$ & 0.844 \\
\hline Known diabetes & 1486 & $1.76(1.40-2.21)$ & $<0.001$ & $1.28(0.88-1.86)$ & 0.015 \\
\hline Immunodepression $^{a}$ & 1479 & $2.21(1.58-3.10)$ & $<0.001$ & $1.08(0.60-1.92)$ & 0.461 \\
\hline Frailty score & 1379 & & $<0.001$ & & $<0.001$ \\
\hline $1-3$ & & - & & - & \\
\hline 4 & & $3.18(2.34-4.33)$ & & $2.22(1.39-3.54)$ & \\
\hline $5-9$ & & $4.23(3.02-5.92)$ & & $1.67(0.92-3.04)$ & \\
\hline Delay between first signs and ICU admission, days & 1424 & & $<0.001$ & & $<0.001$ \\
\hline$<4$ & & - & & - & \\
\hline $4-7$ & & $0.64(0.47-0.88)$ & & $0.67(0.43-1.05)$ & \\
\hline$\geq 8$ & & $0.41(0.30-0.56)$ & & $0.42(0.26-0.66)$ & \\
\hline \multicolumn{6}{|l|}{ During the first $24 \mathrm{~h}$ in ICU } \\
\hline Oxygenation technique & 1491 & & $<0.001$ & & $<0.001$ \\
\hline Standard oxygen & & - & & - & \\
\hline HFNC & & $1.27(0.99-1.63)$ & & $0.90(0.61-1.33)$ & \\
\hline NIV & & $2.64(1.95-3.56)$ & & $2.75(1.79-4.21)$ & \\
\hline Cardiovascular component of the SOFA score $\geq 3$ & 1435 & $1.16(0.64-2.12)$ & 0.630 & $0.75(0.32-1.75)$ & 0.250 \\
\hline Renal component of the SOFA score $\geq 3$ & 1416 & $2.43(1.69-3.49)$ & $<0.001$ & $1.81(1.02-3.20)$ & 0.099 \\
\hline $\mathrm{PaO}_{2} / \mathrm{FiO}_{2}{ }^{\mathrm{b}}, \mathrm{mmHg}$ & 1216 & & $<0.001$ & & $<0.001$ \\
\hline$\leq 100$ & & - & & - & \\
\hline $101-200$ & & $0.68(0.52-0.88)$ & & $0.58(0.41-0.81)$ & \\
\hline $201-300$ & & $0.46(0.29-0.72)$ & & $0.37(0.20-0.68)$ & \\
\hline$>300$ & & $0.24(0.10-0.58)$ & & $0.08(0.01-0.62)$ & \\
\hline Lymphocyte count $<1 \times 10^{9} / \mathrm{L}$ & 1199 & $1.38(1.06-1.80)$ & 0.015 & $0.88(0.62-1.24)$ & 0.646 \\
\hline Platelet count $<150 \times 10^{9} / \mathrm{L}$ & 1342 & $2.16(1.67-2.80)$ & $<0.001$ & $2.02(1.41-2.89)$ & $<0.001$ \\
\hline
\end{tabular}

HR hazard ratio, Cl confidence interval, HFNC high-flow nasal cannula, NIV noninvasive ventilation, SAPS Simplified Acute Physiology Score, SOFA Sequential Organ Failure Assessment, $\mathrm{PaO}_{2} / \mathrm{FiO}_{2}$ partial pressure of oxygen to fraction of inspired oxygen ratio

${ }^{a}$ Defined as hematological malignancies, active solid tumor, or having received specific anti-tumor treatment within a year, solid organ transplant, human immunodeficiency virus, or immunosuppressants

${ }^{b}$ Calculated for all patients, including those on oxygen therapy by using conversion tables provided in the online supplement

disease [28]. Previously, a high tidal volume with NIV has been found to be independently associated with NIV failure [26, 27]. In COVID-19 patients, a retrospective study reported an association between NIV and mortality [18]; however, this association has not been observed in a randomized controlled trial that compared HFNC to helmet NIV [22]. In our patients treated with HFNC, the benefit of HFNC on oxygenation failure did not translate into a 
benefit in terms of mortality. A similar observation has been previously reported in a COVID-19 population [8]. It has also been suspected that HFNC could delay intubation excessively, resulting in more severe lung injury in patients intubated after HFNC failure [15]. However, this hypothesis has not been confirmed by a recent retrospective analysis, which showed similar mortality between patients intubated early after ICU admission and those intubated later [29].

The major strength of this study is the detailed report of clinical features, ventilatory management, and 90-day outcomes of a large, multicenter cohort of COVID-19 patients. We do, however, acknowledge several limitations to our study. First, the oxygenation technique was not randomized and it is possible that more severe patients were more likely to receive HFNC or NIV, precluding definitive conclusions due to be made. This includes the respective impact of HFNC and NIV on oxygenation failure and mortality. Second, the management of patients, and especially of oxygenation techniques and the decision of intubation, were not standardized. However, given the high number of patients, our cohort is likely to reflect the diversity of daily practices across centers. Third, we did not collect certain data that could be pertinent, such as awake prone positioning [30] and the ROX index [17, 31]. Fourth, some variables have missing data (as reported in the tables) due to the large number of patients included in a short period of time with intense clinical activity during the first outbreak of the pandemic. It is, however, of note that the sensitivity analysis with multiple imputations for missing data yielded similar results to the main analysis. Fifth, because the national health system was under extreme pressure with a need for a large number of ICU beds in some regions, we cannot be sure that policies of ICU admission and do-notintubate decisions may have differed between regions and therefore between centers. Finally, we do not provide information on the contamination of caregivers, which could be higher with techniques that could generate a high level of aerosol transmission [9].

\section{Conclusions}

Despite international recommendation and expert viewpoints to the contrary, HFNC and NIV were used increasingly during the first outbreak of the COVID19 pandemics in France, Belgium, and Switzerland. Although HFNC was not associated with a reduction in 90-day mortality, it was associated with less oxygenation failure. This study highlights that HFNC can be useful and as safe as standard oxygen in a large cohort of COVID-19 patients and paves the way for future randomized control trials investigating the benefit of HFNC in these patients. On the contrary, NIV was associated with increased mortality. This observed increased mortality of NIV, if sustained in a prospective randomized trial, would support not using it in COVID-19 patients.

\section{Abbreviations}

ICU: Intensive care unit; HFNC: High-flow nasal cannula; NIV: Noninvasive ventilation; COVID-19: Coronavirus disease 2019; SARS-CoV-2: Severe acute respiratory syndrome coronavirus $2 ; \mathrm{PaO}_{2} / \mathrm{FiO}_{2}$ : Pressure of arterial oxygen to fraction of inspired oxygen concentration.

\section{Supplementary Information}

The online version contains supplementary material available at https://doi. org/10.1186/s13054-021-03784-2.

Additional file 1. Table S1. Estimating inspired fraction of oxygen $\left(\mathrm{FiO}_{2}\right)$ from a given oxygen flow.

Additional file 2. Table S2. Univariate analysis: factors associated with oxygenation failure among patients who were not intubated on the day of intensive care unit (ICU) admission.

Additional file 3. Table S3. Univariate analysis: factors associated with 90-days mortality among patients who were not intubated on the day of intensive care unit (ICU) admission.

Additional file 4. Table S4. Factors associated with 90-days mortality by multivariate analysis among patients who were not intubated on the day of intensive care unit (ICU) admission after multiple imputation for missing data.

\section{Acknowledgements}

Management and Writing Committee: Matthieu Schmidt, MD, PhD, Sorbonne Université, Institute of Cardiometabolism and Nutrition, APHP, Pitié-Salpêtrière Hospital, Medical Intensive Care Unit, Paris, France; Alexandre Demoule, MD, PhD, Sorbonne Université, INSERM, UMRS1158, AP-HP, Groupe Hospitalier Universitaire APHP-Sorbonne Université, Medical Intensive Care Unit and Respiratory Division; David Hajage, MD, PhD, Sorbonne Université, INSERM, Institut Pierre Louis d'Epidémiologie et de Santé Publique, AP-HP, Département de Santé Publique, Centre de Pharmacoépidémiologie, Paris, France; Tài Pham, MD, PhD, Service de Médecine Intensive-Réanimation, Hôpital Bicêtre, AP-HP, Université Paris-Saclay, Le Kremlin-Bicêtre; Alain Combes MD, PhD, Sorbonne Université, Institute of Cardiometabolism and Nutrition, APHP, Pitié-Salpêtrière Hospital, Medical Intensive Care Unit, Paris, France; Martin Dres, MD, PhD, Sorbonne Université, INSERM, UMRS1158, AP-HP, Groupe Hospitalier Universitaire APHP-Sorbonne Université, Medical Intensive Care Unit and Respiratory Division; Said Lebbah, MD, AP-HP, Unité de Recherche Clinique Pitié Salpêtrière Charles Foix, Paris, France; Antoine Kimmoun, MD, PhD, Université de Lorraine, CHRU de Nancy, Service de Médecine Intensive et Réanimation Brabois, INSERM U1116, Vandoeuvre-les-Nancy, France; Alain Mercat, MD, PhD, Département de Médecine Intensive-Réanimation et Médecine Hyperbare, Centre Hospitalier Universitaire d'Angers, Université d'Angers, France; Gaëtan Beduneau, MD, Normandie Univ, UNIROUEN, EA 3830, Rouen University Hospital, Medical Intensive Care Unit, F-76000 Rouen, France; Jessica Palmyre, Sorbonne Université, INSERM, Institut Pierre Louis d'Epidémiologie et de Santé Publique, AP-HP, Département de Santé Publique, Centre de Pharmacoépidémiologie, Paris, France; Margot Prevost, Sorbonne Université, INSERM, Institut Pierre Louis d'Epidémiologie et de Santé Publique, AP-HP, Département de Santé Publique, Centre de Pharmacoépidémiologie, Paris, France; Jean-Damien Ricard, MD, PhD, Service de Médecine IntensiveRéanimation, Hôpital Louis Mourier, Colombes; Alexis Ferré, MD, Intensive Care Unit, Versailles Hospital, Le Chesnay, Fance; Pierre-Marie Fayolle, MD, Service de Réanimation, Centre Hospitalier Universitaire Martinique, Fort de France; Christophe Girault, MD, Normandie Univ, UNIROUEN, EA 3830, Rouen University Hospital, Medical Intensive care Unit, F-76000 Rouen, France; Gael Pradel, MD, Service de Réanimation, Centre Hospitalier Henri Mondor, Aurillac. Participating Sites and COVID-ICU Investigators: CHU Angers, Angers, France (Alain Mercat, Pierre Asfar, François Beloncle, Julien Demiselle), APHP_Hôpital 
Bicêtre, Le Kremlin-Bicêtre, France (Tài Pham, Arthur Pavot, Xavier Monnet, Christian Richard), APHP—Hôpital Pitié Salpêtrière, Paris, France (Alexandre Demoule, Martin Dres, Julien Mayaux, Alexandra Beurton), CHU Caen Normandie-Hôpital Côte de Nacre, Caen, France (Cédric Daubin, Richard Descamps, Aurélie Joret, Damien Du Cheyron), APHP—Hôpital Cochin, Paris, France (Frédéric Pene, Jean-Daniel Chiche, Mathieu Jozwiak, Paul Jaubert), APHP_-Hôpital Tenon, Paris (France, Guillaume Voiriot, Muriel Fartoukh, Marion Teulier, Clarisse Blayau), CHRU de Brest—La Cavale Blanche, Brest, France (Erwen L'Her, Cécile Aubron, Laetitia Bodenes, Nicolas Ferriere), Centre Hospitalier de Cholet, Cholet, France (Johann Auchabie, Anthony Le Meur, Sylvain Pignal, Thierry Mazzoni), CHU Dijon Bourgogne, Dijon, France (Jean-Pierre Quenot, Pascal Andreu, Jean-Baptiste Roudau, Marie Labruyère), CHU Lille-Hôpital Roger Salengero, Lille, France (Saad Nseir, Sébastien Preau, Julien Poissy, Daniel Mathieu), Groupe Hospitalier Nord Essonne, Longjumeau, France (Sarah Benhamida, Rémi Paulet, Nicolas Roucaud, Martial Thyrault), APHM — Hopital Nord, Marseille, France (Florence Daviet, Sami Hraiech, Gabriel Parzy, Aude Sylvestre), Hôpital de Melun-Sénart, Melun, France (Sébastien Jochmans, Anne-Laure Bouilland, Mehran Monchi), Élément Militaire de Réanimation du SSA, Mulhouse, France (Marc Danguy des Déserts, Quentin Mathais, Gwendoline Rager, Pierre Pasquier), CHU Nantes—Hôpital Hotel Dieu, Nantes, France (Reignier Jean, Seguin Amélie, Garret Charlotte, Canet Emmanuel), CHU Nice-Hôpital Archet, Nice, France (Jean Dellamonica, Clément Saccheri, Romain Lombardi, Yanis Kouchit), Centre Hospitalier d'Orléans, Orléans, France (Sophie Jacquier, Armelle Mathonnet, Mai-Ahn Nay, Isabelle Runge), Centre Hospitalier Universitaire de la Guadeloupe, Pointe-àPitre, France (Frédéric Martino, Laure Flurin, Amélie Rolle, Michel Carles), Hôpital de la Milétrie, Poitiers, France (Rémi Coudroy, Arnaud W Thille, Jean-Pierre Frat, Maeva Rodriguez), Centre Hospitalier Roanne, Roanne, France (Pascal Beuret, Audrey Tientcheu, Arthur Vincent, Florian Michelin), CHU Rouen-Hôpital Charles Nicolle, Rouen, France (Fabienne Tamion, Dorothée Carpentier, Déborah Boyer, Christophe Girault ), CHRU Tours-Hôpital Bretonneau, Tours, France (Valérie Gissot, Stéphan Ehrmann, Charlotte Salmon Gandonniere, Djlali Elaroussi), Centre Hospitalier Bretagne Atlantique, Vannes, France (Agathe Delbove, Yannick Fedun, Julien Huntzinger, Eddy Lebas), CHU Liège, Liège, Belgique (Grâce Kisoka, Céline Grégoire, Stella Marchetta, Bernard Lambermont), Hospices Civils de Lyon—Hôpital Edouard Herriot, Lyon, France (Laurent Argaud, Thomas Baudry, Pierre-Jean Bertrand, Auguste Dargent), Centre Hospitalier Du Mans, Le Mans, France (Christophe Guitton, Nicolas Chudeau, Mickaël Landais, Cédric Darreau), Centre Hospitalier de Versailles, Le Chesnay, France (Alexis Ferre, Antoine Gros, Guillaume Lacave, Fabrice Bruneel), Hôpital Foch, Suresnes, France (Mathilde Neuville, JérômeDevaquet, Guillaume Tachon, Richard Gallot), Hôpital Claude Galien, Quincy sous Senart, France (Riad Chelha, Arnaud Galbois, Anne Jallot, Ludivine Chalumeau Lemoine), GHR Mulhouse Sud-Alsace, Mulhouse, France (Khaldoun Kuteifan, Valentin Pointurier, Louise-Marie Jandeaux, Joy Mootien), APHP—Hôpital Antoine Béclère, Clamart, France (Charles Damoisel, Benjamin Sztrymf), APHP_-Hôpital Pitié-Salpêtrière, Paris, France (Matthieu Schmidt, Alain Combes, Juliette Chommeloux, Charles Edouard Luyt), Hôpital Intercommunal de Créteil, Créteil, France (Frédérique Schortgen, Leon Rusel, Camille Jung), Hospices Civils de Lyon—Hôpital Neurologique, Lyon, France (Florent Gobert), APHP—Hôpital Necker, Paris, France (Damien Vimpere, Lionel Lamhaut), Centre Hospitalier Public du Cotentin-Hôpital Pasteur, Cherbourg-en-cotentin, France (Bertrand Sauneuf, Liliane Charrrier, Julien Calus, Isabelle Desmeules), CHU Rennes-Hôpital du Pontchaillou, Rennes, France (Benoît Painvin, Jean-Marc Tadie), CHU Strasbourg — Hôpital Hautepierre, Strasbourg, France (Vincent Castelain, Baptiste Michard, Jean-Etienne Herbrecht, Mathieu Baldacini), APHP_Hôpital Pitié Salpêtrière, Paris, France (Nicolas Weiss, Sophie Demeret, Clémence Marois, Benjamin Rohaut), Centre Hospitalier Territorial Gaston-Bourret, Nouméa, France (Pierre-Henri Moury, Anne-Charlotte Savida, Emmanuel Couadau, Mathieu Série), Centre Hospitalier Compiègne-Noyon, Compiègne, France (Nica Alexandru), Groupe Hospitalier Saint-Joseph, Paris, France (Cédric Bruel, Candice Fontaine, Sonia Garrigou, Juliette Courtiade Mahler), Centre hospitalier mémorial de Saint-Lô, Saint-Lô, France (Maxime Leclerc, Michel Ramakers), Grand Hôpital de l'Est Francilien, Jossigny, France (Pierre Garçon, Nicole Massou, Ly Van Vong, Juliane Sen), Gustave Roussy, Villejuif, France (Nolwenn Lucas, Franck Chemouni, Annabelle Stoclin), Centre Hospitalier Intercommunal Robert Ballanger, Aulnay-sous-Bois, France (Alexandre Avenel, Henri Faure, Angélie Gentilhomme, Sylvie Ricome), Hospices Civiles de Lyon—Hôpital Edouard Herriot, Lyon, France (Paul Abraham, Céline Monard, Julien Textoris, Thomas Rimmele), Centre Hospitalier d'Avignon, Avignon, France (Florent Montini), Groupe Hospitalier
Diaconesses - Croix Saint Simon, Paris, France (Gabriel Lejour, Thierry Lazard, Isabelle Etienney, Younes Kerroumi), CHU Clermont-Ferrand-Hôpital Gabriel Montpied, Clermont Ferrand, France (Claire Dupuis, Marine Bereiziat, Elisabeth Coupez, François Thouy), Hôpital d'Instruction des Armées Percy, Clamart, France (Clément Hoffmann, Nicolas Donat, Anne Chrisment, Rose-Marie Blot), CHU Nancy_-Hôpital Brabois, Vandoeuvre-les-Nancy, France (Antoine Kimmoun, Audrey Jacquot, Matthieu Mattei, Bruno Levy), Centre Hospitalier de Vichy, Vichy, France (Ramin Ravan, Loïc Dopeux, Jean-Mathias Liteaudon, Delphine Roux), Hopital Pierre Bérégovoy, Nevers, France (Brice Rey, Radu Anghel, Deborah Schenesse, Vincent Gevrey), Centre Hospitalier de Tarbes, Tarbes, France (Jermy Castanera, Philippe Petua, Benjamin Madeux), Hôpitaux Civils de Colmar-Hôpital Louis pasteur, Colmar, France (Otto Hartman), CHU Charleroi-Hôpital Marie Curie, Bruxelles, Belgique (Michael Piagnerelli, Anne Joosten,Cinderella Noel, Patrick Biston), Centre hospitalier de Verdun Saint Mihiel, Saint Mihiel, France (Thibaut Noel), CH Eure-Seine-Hôpital d'Evreux-Vernon, Evreux, France (Gurvan LE Bouar, Messabi Boukhanza, Elsa Demarest, Marie-France Bajolet), Hôpital René Dubos, Pontoise, France (Nathanaël Charrier, Audrey Quenet, Cécile Zylberfajn, Nicolas Dufour), APHP_Hôpital Lariboisière, Paris, France (Buno Mégarbane, SqébastianVoicu, Nicolas Deye, Isabelle Malissin), Centre Hospitalier de Saint-Brieuc, Saint-Brieuc, France (François Legay, Matthieu Debarre, Nicolas Barbarot, Pierre Fillatre), Polyclinique Bordeaux Nord Aquitaine, Bordeaux, France (Bertrand Delord, Thomas Laterrade, Tahar Saghi, Wilfried Pujol), HIA Sainte Anne, Toulon, France (Pierre Julien Cungi, Pierre Esnault, Mickael Cardinale), Grand Hôpital de l'Est Francilien, Meaux, France (Vivien Hong Tuan Ha, Grégory Fleury, Marie-Ange Brou, Daniel Zafimahazo), HIA Robert Picqué, Villenave d'Ornon, France (David Tran-Van, Patrick Avargues, Lisa Carenco), Centre Hospitalier Fontainebleau, Fontainebleau, France (Nicolas Robin, Alexandre Ouali, Lucie Houdou), Hôpital Universitaire de Genève, Genève, Suisse (Christophe Le Terrier, NoémieSuh, Steve Primmaz, JéromePugin), APHP—Hôpital Beaujon, Clichy, France (Emmanuel Weiss, Tobias Gauss, Jean-Denis Moyer, Catherine Paugam Burtz), Groupe Hospitalier Bretage Sud, Lorient, France (Béatrice La Combe, Rolland Smonig, Jade Violleau, Pauline Cailliez), Centre Hospitalier Intercommunal Toulon, La Seyne sur Mer, France (Jonathan Chelly), Centre Hospitalier de Dieppe, Dieppe, France (Antoine Marchalot, Cécile Saladin, Christelle Bigot), CHU de Martinique, Fort-de-France, France (Pierre-Marie Fayolle, Jules Fatséas, Amr Ibrahim, Dabor Resiere), Hôpital Fondation Adolphe de Rothchild, Paris, France (Rabih Hage, Clémentine Cholet, Marie Cantier, Pierre Trouiler), APHP_Bichat Claude Bernard, Paris, France (Philippe Montravers, Brice Lortat-Jacob, Sebastien Tanaka, Alexy Tran Dinh), APHP—Hôpital Universitaire Paris Sud, Bicêtre, France (Jacques Duranteau, Anatole Harrois, Guillaume Dubreuil, Marie Werner), APHP_-Hôpital Européen Georges Pompidou, Paris, France (Anne Godier, Sophie Hamada, Diane Zlotnik, Hélène Nougue) , APHP, GHU Henri Mondor, Créteil, France (Armand Mekontso-Dessap, Guillaume Carteaux, Keyvan Razazi, Nicolas De Prost), APHP—Hôpitaux Universitaires Henri Mondor, Créteil, France (Nicolas Mongardon, Olivier Langeron, Eric Levesque, Arié Attias), APHP—Hôpital Lariboisière, Paris, France (Charles de Roquetaillade, Benjamin G. Chousterman, Alexandre Mebazaa, Etienne Gayat), APHP_-Hôpital Saint-Antoine, Paris, France (Marc Garnier, Emmanuel Pardo, LeaSatre-Buisson, Christophe Gutton), APHP Hôpital Saint-Louis, Paris, France (Elise Yvin, Clémence Marcault, Elie Azoulay, Michael Darmon), APHP—Hôpital Saint-Antoine, Paris, France (Hafid Ait Oufella, Geoffroy Hariri, Tomas Urbina, Sandie Mazerand), APHP—Hôpital Raymond Pointcarré, Garches, France (Nicholas Heming, Francesca Santi, Pierre Moine, Djillali Annane), APHPHôpital Pitié Salpêtrière, Paris, France (Adrien Bouglé, Edris Omar, Aymeric Lancelot, Emmanuelle Begot), Centre Hospitalier Victor Dupouy, Argenteuil, France (Gaétan Plantefeve, Damien Contou, Hervé Mentec, Olivier Pajot), CHU Toulouse — Hôpital Rangueil, Toulouse, France (Stanislas Faguer, Olivier Cointault, Laurence Lavayssiere, Marie-Béatrice Nogier), Centre Hospitalier de Poissy, Poissy, France (Matthieu Jamme, Claire Pichereau, Jan Hayon, Hervé Outin), APHP—Hôpital Saint-Louis, Paris, France (François Dépret, Maxime Coutrot, Maité Chaussard, Lucie Guillemet), Clinique du MontLégia, CHC Groupe-Santé, Liège, Belgique (Pierre Goffin, Romain Thouny, Julien Guntz, Laurent Jadot), CHU Saint-Denis, La Réunion, France (Romain Persichini), Centre Hospitalier de Tourcoing, Tourcoing, France (Vanessa Jean-Michel, Hugues Georges, Thomas Caulier), Centre Hospitalier Henri Mondor d'Aurillac, Aurillac, France (Gaël Pradel, Marie-Hélène Hausermann, Thi My Hue Nguyen-Valat, Michel Boudinaud), Centre Hospitalier Saint Joseph Saint Luc, Lyon, France (Emmanuel Vivier, SylvèneRosseli, Gaël Bourdin, Christian Pommier) Centre Hospitalier de Polynésie Française, Polynésie, France (Marc Vinclair, Simon Poignant, Sandrine Mons), Ramsay Générale de Santé, Hôpital 
Privé Jacques Cartier, Massy, France (Wulfran Bougouin), Centre Hospitalier Alpes Léman, Contamine sur Arve, France (Franklin Bruna, Quentin Maestraggi, Christian Roth), Hospices Civils de Lyon-Hôpital de la Croix Rousse, Lyon, France (Laurent Bitker, François Dhelft, Justine Bonnet-Chateau, Mathilde Filippelli), Centre Cardiologique du Nord, Saint-Denis, France (Tristan Morichau-Beauchant, Stéphane Thierry, Charlotte Le Roy, Mélanie Saint Jouan), GHU—Hôpital Saint-Anne, Paris, France (Bruno Goncalves, Aurélien Mazeraud, Matthieu Daniel, Tarek Sharshar) CHR Metz-Hôpital Mercy, Metz, France (Cyril Cadoz, RostaneGaci, Sébastien Gette, Guillaune Louis), APHP_-Hôpital Paul Brousse, Villejuif, France (Sophe-Caroline Sacleux, Marie-Amélie Ordan), CHRU Nancy_-Hôpital Central, Nancy, France (Aurélie Cravoisy, Marie Conrad, Guilhem Courte, Sébastien Gibot), Centre Hospitalier d'Ajaccio, Ajaccio, France (Younès Benzidi, Claudia Casella, Laurent Serpin, Jean-Lou Setti), Centre Hospitalier de Bourges, Bourges, France (Marie-Catherine Besse, Anna Bourreau), Centre hospitalier de la Côte Basque, Bayonne, France (Jérôme Pillot, Caroline Rivera, Camille Vinclair, Marie-Aline Robaux), Hospices Civils de Lyon-Hôpital de la Croix Rousse, Lyon, France (Chloé Achino, Marie-Charlotte Delignette, Tessa Mazard, Frédéric Aubrun), CH Saint-Malo, Saint-Malo, France (Bruno Bouchet, Aurélien Frérou, Laura Muller, Charlotte Quentin), Centre Hospitalier de Mulhouse, Mulhouse, France (Samuel Degoul), Centre Hospitalier de Briançon, Briançon, France (Xavier Stihle, Claude Sumian, Nicoletta Bergero, Bernard Lanaspre), CHU Nice, Hôpital Pasteur 2, Nice, France (Hervé Quintard, Eve Marie Maiziere), Centre Hospitalier des Pays de Morlaix, Morlaix, France (Pierre-Yves Egreteau, Guillaume Leloup, Florin Berteau, Marjolaine Cottrel), Centre Hospitalier Valence, Valence, France (Marie Bouteloup, Matthieu Jeannot, Quentin Blanc, Julien Saison), Centre Hospitalier Niort, Niort, France (Isabelle Geneau, Romaric Grenot, Abdel Ouchike, Pascal Hazera), APHP_-Hôpital Pitié Salpêtrière, Paris, France (Anne-Lyse Masse, Suela Demiri, Corinne Vezinet, Elodie Baron, Deborah Benchetrit, Antoine Monsel), Clinique du Val d'Or, Saint Cloud, France (Grégoire Trebbia, Emmanuelle Schaack, Raphaël Lepecq, Mathieu Bobet), Centre Hospitalier de Béthune, Béthune, France (Christophe Vinsonneau, Thibault Dekeyser, Quentin Delforge, Imen Rahmani), Groupe Hospitalier Intercommunal de la Haute-Saône, Vesoul, France (Bérengère Vivet, Jonathan Paillot, Lucie Hierle, Claire Chaignat, Sarah Valette), Clinique Saint-Martin, Caen, France (BenoïtHer, Jennifier Brunet), Ramsay Générale de Santé, Clinique Convert, Bourg en Bresse, France (Mathieu Page, Fabienne Boiste, Anthony Collin), Hôpital Victor Jousselin, Dreux, France(Florent Bavozet, Aude Garin ,Mohamed Dlala, KaisMhamdi), Centre Hospitalier de Troye, Troye, France (Bassem Beilouny, Alexandra Lavalard, Severine Perez), CHU de ROUEN-Hôpital Charles Nicolle, Rouen, France (Benoit Veber, Pierre-Gildas Guitard, Philippe Gouin, Anna Lamacz), Centre Hospitalier Agen-Nérac, Agen, France (Fabienne Plouvier, Bertrand P Delaborde, AïssaKherchache, Amina Chaalal), APHP_-Hôpital Louis Mourier, Colombes, France (Jean-Damien Ricard, Marc Amouretti, Santiago FreitaRamos, Damien Roux), APHP_Hôpital Pitié-Salpêtrière, Paris, France (Jean-Michel Constantin, Mona Assefi, Marine Lecore, Agathe Selves), Institut Mutualiste Montsouris, Paris, France (Florian Prevost, Christian Lamer, Ruiying Shi, Lyes Knani), CHU Besançon-Hôpital Jean Minjoz, Besançon, France (Sébastien Pili Floury, Lucie Vettoretti), APHP—Hôpital Universitaire Robert-Debré, Paris, France (Michael Levy, Lucile Marsac, Stéphane Dauger, Sophie Guilmin-Crépon), CHU Besançon-Hôpital Jean Minjoz, Besançon, France (Hadrien Winiszewski, Gael Piton, Thibaud Soumagne, Gilles Capellier); Médipôle Lyon-Villeurbanne, Vileurbanne, France (Jean-Baptiste Putegnat, Frédérique Bayle, Maya Perrou, Ghyslaine Thao), APHP_Ambroise Paré, Boulogne-Billancourt, France (Guillaume Géri, Cyril Charron, Xavier Repessé, Antoine Vieillard-Baron), CHU Amiens Picardie, Amiens, France (Mathieu Guilbart, Pierre-Alexandre Roger, Sébastien Hinard, Pierre-Yves Macq), Hôpital Nord-Ouest, Villefranche-sur-Saône, France (Kevin Chaulier, Sylvie Goutte), CH de Châlons en Champagne, Châlons en Champagne, France (Patrick Chillet, Anaïs Pitta, Barbara Darjent, Amandine Bruneau), CHU Angers, Angers, France (Sigismond Lasocki, Maxime Leger, Soizic Gergaud, Pierre Lemarie), CHU Grenoble Alpes, Grenoble, France (Nicolas Terzi, Carole Schwebel, Anaïs Dartevel, Louis-Marie Galerneau), APHP_-Hôpital Européen Georges Pompidou, Paris, France (Jean-Luc Diehl, Caroline Hauw-Berlemont, Nicolas Péron, Emmanuel Guérot), Hôpital Privé d'Antony, Antony, France (Abolfazl Mohebbi Amoli, Michel Benhamou, Jean-Pierre Deyme, Olivier Andremont), Institut Arnault Tzanck,Saint Laurent du Var, France (Diane Lena, Julien Cady, Arnaud Causeret, Arnaud De La Chapelle); Centre Hospitalier d'Angoulême, Angoulême, France (Christophe Cracco, Stéphane Rouleau, David Schnell); Centre Hospitalier de Cahors, Cahors, France (Camille Foucault), Centre hospitalier de Carcassonne, Carcassonne, France (Cécile Lory); CHU
Nice-Hôpital L'Archet 2, Nice, France (Thibault Chapelle, Vincent Bruckert, Julie Garcia, Abdlazize Sahraoui); Hôpital Privé du Vert Galant, Tremblay-enFrance, France (Nathalie Abbosh, Caroline Bornstain, Pierre Pernet); Centre Hospitalier de Rambouillet, Rambouillet, France (Florent Poirson, Ahmed Pasem, Philippe Karoubi); Hopitaux du Léman, Thonon les Bains, France (Virginie Poupinel, Caroline Gauthier, François Bouniol, Philippe Feuchere), Centre Hospitalier Victor Jousselin, Dreux, France (Florent Bavozet, Anne Heron), Hôpital Sainte Camille, Brie sur Marne, France (Serge Carreira, Malo Emery, Anne Sophie Le Floch, Luana Giovannangeli), Hôpital d'instruction des armées Clermont-Tonnerre, Brest, France (Nicolas Herzog, Christophe Giacardi, Thibaut Baudic, Chloé Thill), APHP—Hôpital Pitié Salpêtrière, Paris, France (Said Lebbah, Jessica Palmyre, Florence Tubach, David Hajage); APHP—Hôpital Avicenne, Bobigny, France (Nicolas Bonnet, Nathan Ebstein, Stéphane Gaudry, Yves Cohen); Groupement Hospitalier la Rochelle Ré Amis, La Rochelle, France (Julie Noublanche, Olivier Lesieur); Centre Hospitalier Intercommunal de Mont de Marsan et du Pays des Sources, Mont de Marsan, France (Arnaud Sément, Isabel Roca-Cerezo, Michel Pascal, Nesrine Sma); Centre Hospitalier Départemental de Vendée, La-Roche-Sur-Yon, France (Gwenhaël Colin, Jean-Claude Lacherade, Gauthier Bionz, Natacha Maquigneau); Pôle Anesthésie-Réanimation, CHU Grenoble (Pierre Bouzat, Michel Durand, Marie-Christine Hérault, Jean-Francois Payen).

\section{Authors' contributions}

$A D, M S, S L$, and $\mathrm{DH}$ had full access to all of the data in the study and take responsibility for the integrity of the data and the accuracy of the data analysis. GB, AC, AD, MD, DH, AK, AM, TP, MS, JDR, AF, PMF, CG, and GP contributed to concept and design. $\mathrm{DH}$ and $\mathrm{SL}$ contributed to methodology. AC, AD, MD, $\mathrm{DH}, \mathrm{AK}, \mathrm{AM}, \mathrm{TP}, \mathrm{MS}, \mathrm{JDR}, \mathrm{AF}, \mathrm{PMF}, \mathrm{CG}$, and GP performed acquisition, analysis, or interpretation of data. $A D, D H, M S$, and $S L$ drafted the manuscript. $G B, M D, A K$ AM, TP JDR, AF, PMF, CG, and GP critical revised the manuscript for important intellectual content. DH and SL did statistical analysis. MS, AD, and AM supervised the study. AD, DH, JP, MS, and AM obtained funding. JP and FP provided administrative, technical, or material support. All authors read and approved the final manuscript.

\section{Funding}

This study was funded by the Fondation APHP and its donators though the program "Alliance Tous Unis Contre le Virus," the Direction de la Recherche Clinique et du Développement, and the French Ministry of Health. The Reseau European de recherche en Ventilation Artificielle (REVA) network received a $75,000 €$ research grant from Air Liquide Healthcare. The funders had no role in the design and conduct of the study; collection, management, analysis, and interpretation of the data; preparation, review, or approval of the manuscript; and decision to submit the manuscript for publication.

\section{Availability of supporting data}

The datasets used and/or analyzed during the current study are available from the corresponding author on reasonable request.

\section{Declarations}

\section{Ethics approval and consent to participate}

This study received approval from the ethical committee of the French Intensive Care Society (CE-SRLF 20-23) in accordance with local regulations. All patients or close relatives were informed that their data were included in the COVID-ICU cohort.

\section{Consent for publication}

Not applicable.

\section{Competing interests}

MS reported personal fees from Getinge, Drager, and Xenios, outside the submitted work. AD reports personal fees from Medtronic, grants, personal fees, and non-financial support from Philips, personal fees from Baxter, personal fees from Hamilton, personal fees and non-financial support from Fisher \& Paykel, grants from French Ministry of Health, personal fees from Getinge, grants and personal fees from Respinor, grants and non-financial support from Lungpacer, outside the submitted work. AM reported personal fees from Faron Pharmaceuticals, Air Liquid Medical Systems, Pfizer, Resmed and Draeger and grants and personal fees from Fisher and Paykel and Covidien, outside this 
work. MD reported personal fees from Lungpacer. AK reported personal fees from Aspen, Aguettant, and MSD. CG reported receiving grants, personal fees, and nonfinancial support from Fisher \& Paykel Healthcare and grants and nonfinancial support from ResMed outside the submitted work. JRD reported receiving travel and accommodation expenses from Fisher \& Paykel Healthcare outside the submitted work. No other disclosures were reported.

Received: 10 August 2021 Accepted: 6 October 2021 Published online: 08 December 2021

\section{References}

1. Mauri T, Alban L, Turrini C, Cambiaghi B, Carlesso E, Taccone P, Bottino N, Lissoni A, Spadaro S, Volta CA, Gattinoni L, Pesenti A, Grasselli G. Optimum support by high-flow nasal cannula in acute hypoxemic respiratory failure: effects of increasing flow rates. Intensive Care Med. 2017;43:1453-63.

2. Mauri T, Turrini C, Eronia N, Grasselli G, Volta CA, Bellani G, Pesenti A. Physiologic effects of high-flow nasal cannula in acute hypoxemic respiratory failure. Am J Respir Crit Care Med. 2017;195:1207-15.

3. L'Her E, Deye N, Lellouche F, Taille S, Demoule A, Fraticelli A, Mancebo J, Brochard L. Physiologic effects of noninvasive ventilation during acute lung injury. Am J Respir Crit Care Med. 2005;172:1112-8.

4. Rochwerg B, Granton D, Wang DX, Helviz Y, Einav S, Frat JP, MekontsoDessap A, Schreiber A, Azoulay E, Mercat A, Demoule A, Lemiale V, Pesenti A, Riviello ED, Mauri T, Mancebo J, Brochard L, Burns K. High flow nasal cannula compared with conventional oxygen therapy for acute hypoxemic respiratory failure: a systematic review and meta-analysis. Intensive Care Med. 2019;45:563-72.

5. Rochwerg B, Einav S, Chaudhuri D, Mancebo J, Mauri T, Helviz Y, Goligher EC, Jaber S, Ricard J-D, Rittayamai N, Roca O, Antonelli M, Maggiore SM, Demoule A, Hodgson CL, Mercat A, Wilcox ME, Granton D, Wang D, Azoulay E, Ouanes-Besbes L, Cinnella G, Rauseo M, Carvalho C, DessapMekontso A, Fraser J, Frat J-P, Gomersall C, Grasselli G, et al. The role for high flow nasal cannula as a respiratory support strategy in adults: a clinical practice guideline. Intensive Care Med. 2020;46:2226-37.

6. Rochwerg B, Brochard L, Elliott MW, Hess D, Hill NS, Nava S, Navalesi P, Antonelli M, Brozek J, Conti G, Ferrer M, Guntupalli K, Jaber S, Keenan S, Mancebo J, Mehta S, Raoof S. Official ERS/ATS clinical practice guidelines: noninvasive ventilation for acute respiratory failure. Eur Respir J 2017;50:

7. Demoule A, Girou E, Richard J-C, Taille S, Brochard L. Benefits and risks of success or failure of noninvasive ventilation. Intensive Care Med. 2006;32:1756-65.

8. Demoule A, Vieillard Baron A, Darmon M, Beurton A, Géri G, Voiriot G, Dupont T, Zafrani L, Girodias L, Labbé V, Dres M, Fartoukh M, Azoulay E. High-flow nasal cannula in critically III patients with severe COVID-19. Am J Respir Crit Care Med. 2020;202:1039-42.

9. Franco C, Facciolongo N, Tonelli R, Dongilli R, Vianello A, Pisani L, Scala R, Malerba M, Carlucci A, Negri EA, Spoladore G, Arcaro G, Tillio PA, Lastoria C, Schifino G, Tabbì L, Guidelli L, Guaraldi G, Ranieri VM, Clini E, Nava S. Feasibility and clinical impact of out-of-ICU noninvasive respiratory support in patients with COVID-19-related pneumonia. Eur Respir J 2020;56:

10. COVID-ICU Group on behalf of the REVA Network and the COVID-ICU Investigators. Clinical characteristics and day-90 outcomes of 4244 critically ill adults with COVID-19: a prospective cohort study. Intensive Care Med 2020; doi:https://doi.org/10.1007/s00134-020-06294-x.

11. Le Gall JR, Lemeshow S, Saulnier F. A new Simplified Acute Physiology Score (SAPS II) based on a European/North American multicenter study. JAMA. 1993;270:2957-63.

12. Vincent JL, Moreno R, Takala J, Willatts S, De Mendonça A, Bruining H, Reinhart CK, Suter PM, Thijs LG. The SOFA (Sepsis-related Organ Failure Assessment) score to describe organ dysfunction/failure. On behalf of the Working Group on Sepsis-Related Problems of the European Society of Intensive Care Medicine. Intensive Care Med 1996;22:707-710.

13. Juma S, Taabazuing M-M, Montero-Odasso M. Clinical frailty scale in an acute medicine unit: a simple tool that predicts length of stay. Can Geriatr J. 2016;19:34-9.

14. Alhazzani W, Møller MH, Arabi YM, Loeb M, Gong MN, Fan E, Oczkowski S, Levy MM, Derde L, Dzierba A, Du B, Aboodi M, Wunsch H, Cecconi M, Koh Y, Chertow DS, Maitland K, Alshamsi F, Belley-Cote E, Greco M, Laundy M,
Morgan JS, Kesecioglu J, McGeer A, Mermel L, Mammen MJ, Alexander PE, Arrington A, Centofanti JE, et al. Surviving sepsis campaign: guidelines on the management of critically III Adults with Coronavirus Disease 2019 (COVID-19). Crit Care Med. 2020;48:e440-69.

15. Marini JJ, Gattinoni L. Management of COVID-19 respiratory distress. JAMA. 2020;323:2329-30.

16. Beduneau G, Boyer D, Guitard P-G, Gouin P, Carpentier D, Grangé S, Veber B, Girault C, Tamion F. Covid-19 severe hypoxemic pneumonia: a clinical experience using high-flow nasal oxygen therapy as first-line management. Respir Med Res 2021;80:100834.

17. Zucman N, Mullaert J, Roux D, Roca O, Ricard J-D, Contributors. Prediction of outcome of nasal high flow use during COVID-19-related acute hypoxemic respiratory failure. Intensive Care Med 2020;46:1924-1926.

18. Wendel Garcia PD, Aguirre-Bermeo H, Buehler PK, Alfaro-Farias M, Yuen B, David S, Tschoellitsch T, Wengenmayer T, Korsos A, Fogagnolo A, Kleger G-R, Wu MA, Colombo R, Turrini F, Potalivo A, Rezoagli E, RodríguezGarcía R, Castro P, Lander-Azcona A, Martín-Delgado MC, Lozano-Gómez $H$, Ensner R, Michot MP, Gehring N, Schott P, Siegemund M, Merki L, Wiegand J, Jeitziner MM, et al. Implications of early respiratory support strategies on disease progression in critical COVID-19: a matched subanalysis of the prospective RISC-19-ICU cohort. Crit Care. 2021;25:175.

19. Cummings MJ, Baldwin MR, Abrams D, Jacobson SD, Meyer BJ, Balough EM, Aaron JG, Claassen J, Rabbani LE, Hastie J, Hochman BR, SalazarSchicchi J, Yip NH, Brodie D, O’Donnell MR. Epidemiology, clinical course, and outcomes of critically ill adults with COVID-19 in New York City: a prospective cohort study. Lancet. 2020;395:1763-70.

20. Karagiannidis C, Mostert C, Hentschker C, Voshaar T, Malzahn J, Schillinger G, Klauber J, Janssens U, Marx G, Weber-Carstens S, Kluge S, Pfeifer M, Grabenhenrich L, Welte T, Busse R. Case characteristics, resource use, and outcomes of 10,021 patients with COVID-19 admitted to 920 German hospitals: an observational study. Lancet Respir Med. 2020;8:853-62.

21. Bellani G, Laffey JG, Pham T, Madotto F, Fan E, Brochard L, Esteban A, Gattinoni L, Bumbasirevic V, Piquilloud L, van Haren F, Larsson A, McAuley DF, Bauer PR, Arabi YM, Ranieri M, Antonelli M, Rubenfeld GD, Thompson BT, Wrigge H, Slutsky AS, Pesenti A, LUNG SAFE Investigators, ESICM Trials Group. Noninvasive ventilation of patients with acute respiratory distress syndrome. insights from the LUNG SAFE Study. Am J Respir Crit Care Med 2017;195:67-77.

22. Grieco DL, Menga LS, Cesarano M, Rosà T, Spadaro S, Bitondo MM, Montomoli J, Falò G, Tonetti T, Cutuli SL, Pintaudi G, Tanzarella ES, Piervincenzi E, Bongiovanni F, Dell'Anna AM, Delle Cese L, Berardi C, Carelli S, Bocci MG, Montini L, Bello G, Natalini D, De Pascale G, Velardo M, Volta CA, Ranieri VM, Conti G, Maggiore SM, Antonelli M, et al. Effect of helmet noninvasive ventilation vs high-flow nasal oxygen on days free of respiratory support in patients with COVID-19 and moderate to severe hypoxemic respiratory failure: the HENIVOT Randomized Clinical Trial. JAMA. 2021;325:1731-43.

23. Frat J-P, Thille AW, Mercat A, Girault C, Ragot S, Perbet S, Prat G, Boulain T, Morawiec E, Cottereau A, Devaquet J, Nseir S, Razazi K, Mira J-P, Argaud L, Chakarian J-C, Ricard J-D, Wittebole X, Chevalier S, Herbland A, Fartoukh M, Constantin J-M, Tonnelier J-M, Pierrot M, Mathonnet A, Béduneau G, Delétage-Métreau C, Richard J-CM, Brochard L, et al. High-flow oxygen through nasal cannula in acute hypoxemic respiratory failure. N Engl J Med 2015:372:2185-96.

24. Azoulay E, Kouatchet A, Jaber S, Lambert J, Meziani F, Schmidt M, Schnell D, Mortaza S, Conseil M, Tchenio X, Herbeca P, Andrivet P, Guerot E, Lafabrie A, Perbet S, Camous L, Janssen-Langenstein R, Collet F, Messika J, Legriel S, Fabre X, Guisset O, Touati S, Kilani S, Alves M, Mercat A, Similowski T, Papazian L, Meert A-P, et al. Noninvasive mechanical ventilation in patients having declined tracheal intubation. Intensive Care Med. 2013;39:292-301.

25. Ricard J-D, Roca O, Lemiale V, Corley A, Braunlich J, Jones P, Kang BJ, Lellouche F, Nava S, Rittayamai N, Spoletini G, Jaber S, Hernandez G. Use of nasal high flow oxygen during acute respiratory failure. Intensive Care Med. 2020. https://doi.org/10.1007/s00134-020-06228-7.

26. Carteaux G, Millán-Guilarte T, De Prost N, Razazi K, Abid S, Thille AW, Schortgen F, Brochard L, Brun-Buisson C, Mekontso DA. Failure of noninvasive ventilation for de novo acute hypoxemic respiratory failure: role of tidal volume. Crit Care Med. 2016:44:282-90.

27. Frat J-P, Ragot S, Coudroy R, Constantin J-M, Girault C, Prat G, Boulain T, Demoule A, Ricard J-D, Razazi K, Lascarrou J-B, Devaquet J, Mira J-P, Argaud L, Chakarian J-C, Fartoukh M, Nseir S, Mercat A, Brochard L, Robert 
R, Thille AW, REVA network. Predictors of intubation in patients with acute hypoxemic respiratory failure treated with a noninvasive oxygenation strategy. Crit Care Med 2018;46:208-215.

28. Brochard L, Slutsky A, Pesenti A. Mechanical ventilation to minimize progression of lung injury in acute respiratory failure. Am J Respir Crit Care Med. 2017;195:438-42.

29. Dupuis C, Bouadma L, de Montmollin E, Goldgran-Toledano D, Schwebel C, Reignier J, Neuville M, Ursino M, Siami S, Ruckly S, Alberti C, Mourvillier B, Bailly S, Grapin K, Laurent V, Buetti N, Gainnier M, Souweine B, Timsit J-F. Association between early invasive mechanical ventilation and day-60 mortality in acute hypoxemic respiratory failure related to coronavirus disease-2019 pneumonia. Crit Care Explor 2021;3:e0329.

30. Coppo A, Bellani G, Winterton D, Di Pierro M, Soria A, Faverio P, Cairo M, Mori S, Messinesi G, Contro E, Bonfanti P, Benini A, Valsecchi MG, Antolini $L$, Foti G. Feasibility and physiological effects of prone positioning in nonintubated patients with acute respiratory failure due to COVID-19 (PRONCOVID): a prospective cohort study. Lancet Respir Med. 2020;8:765-74.

31. Roca O, Caralt B, Messika J, Samper M, Sztrymf B, Hernández G, García-deAcilu M, Frat J-P, Masclans JR, Ricard J-D. An index combining respiratory rate and oxygenation to predict outcome of nasal high-flow therapy. Am J Respir Crit Care Med. 2019;199:1368-76.

\section{Publisher's Note}

Springer Nature remains neutral with regard to jurisdictional claims in published maps and institutional affiliations.

- fast, convenient online submission

- thorough peer review by experienced researchers in your field

- rapid publication on acceptance

- support for research data, including large and complex data types

- gold Open Access which fosters wider collaboration and increased citations

- maximum visibility for your research: over $100 \mathrm{M}$ website views per year

At BMC, research is always in progress.

Learn more biomedcentral.com/submissions 